\title{
An unusual cause of neonatal ascites
}

\author{
Rita Espírito Santo, Rosa Martins, Sandra Valente, Joana Saldanha
}

Paediatrics Department, Hospital Santa Maria, Centro Hospitalar Lisboa Norte, Lisboa, Portugal

\section{Correspondence to} Dr Rita Espírito Santo, a.r.espiritosanto@gmail.com

Accepted 21 April 2017
CrossMark

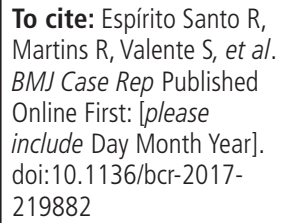

\section{DESCRIPTION}

A 30-year-old primigravida was referred to our institution due to an isolated fetal ascites (IFA). The gestation was uneventful until the 32 nd week when the mother was hospitalised due to refractory hypertension. An ultrasound revealed a fetal abdominal circumference above percentile 99. Fetal parameters and amniotic fluid volume were normal.and

The investigation of IFA was started on the mother: blood type was $\mathrm{ARh}+$, indirect Coombs test and infectious serology (toxoplasmosis, syphilis, varicella-zoster, parvovirus B19, rubella, cytomegalovirus and herpes (TORCH)) were negative.

A spontaneous vaginal delivery occurred at 34 weeks. As the ascites compromised ventilation, the neonate was intubated and an urgent paracentesis was performed evacuating $175 \mathrm{~mL}$ of a transudate, and thereafter, the caucasian female neonate with $2235 \mathrm{~g}$ was stable with spontaneous breathing.

As the ascites persisted, the investigation continued on the neonate: blood group $\mathrm{ARh}+$, negative direct Coombs test and normal echocardiography. Abdominal ultrasound showed dilated bowel loops. The abdominal X-ray revealed three hypertransparent images (figure 1), suggestive of a gastrointestinal anomaly.

On the next day, there was a clinical (figure 2) and radiological worsening (figure 3). So an exploratory laparotomy was performed. A mesenteric defect, with intestinal malrotation and internal hernia was diagnosed. After surgery, she had a significant ponderal loss with a slow

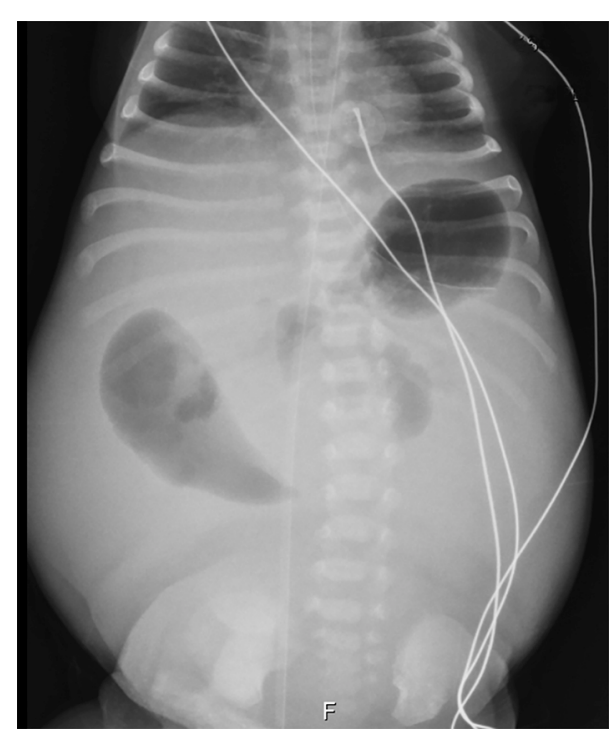

Figure 1 The abdominal X-ray on the first day that revealed three conic hypertransparent images.

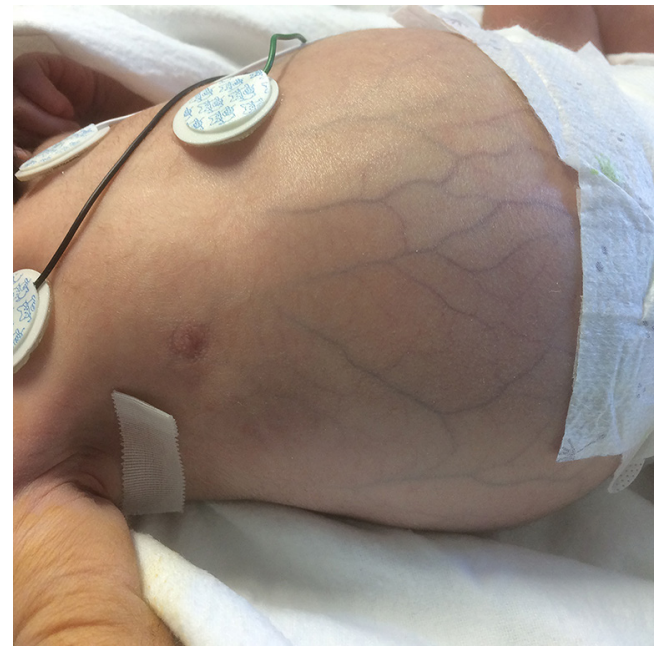

Figure 2 Clinical worsening at day 2 of life: abdominal distension and collateral vasculature.

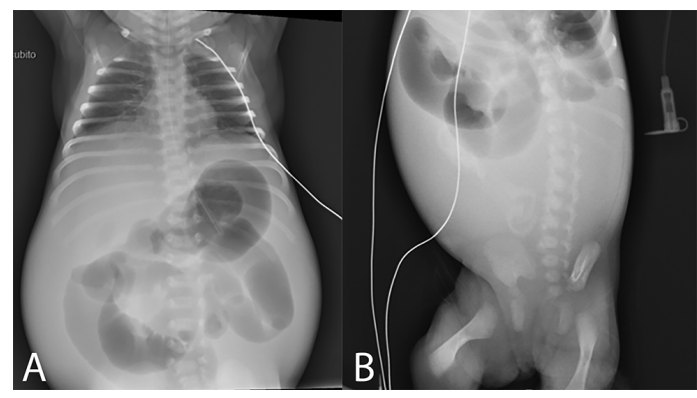

Figure 3 Radiological worsening at day 2 of life: (A) dilated bowel loops and (B) absence of air in the inferior portion of the abdomen.

\section{Learning points}

-When ascites is identifiable in fetal period, the investigation should start in the mother with blood group test, indirect Coombs test, amniocentesis and screening of G6DP deficiency, thalassaemia and TORCH infections. If the ascites persists after birth, the search for an aetiology should continue in the infant with blood group test, direct Coombs test, karyotype, echocardiography, abdominal X-ray and ultrasound. ${ }^{13}$

- The cases of isolated fetal ascites (IFA) should be referred to a hospital with tertiary centre. At birth, due to the ascites, ventilation of these neonates can be compromised, so an urgent paracentesis will be needed in the delivery room.

- If the cause of IFA is an abdominal anomaly, cystic fibrosis should be always a diagnosis to consider. ${ }^{1}$ 
weight gain. The screening for cystic fibrosis (CF) was positive ( $\Delta$ F508 homozygous).

At 3 months, she was discharged and referred to CF centre.

IFA is a condition with heterogeneous aetiology: isoimmunisation, congenital infections, chromosomopathies, cardiac, genitourinary and gastrointestinal malformations. ${ }^{1-3} \mathrm{CF}$ has been associated with gastrointestinal anomalies that manifest as IFA. ${ }^{1}$ Nevertheless, we think this is the first case relating CF with congenital mesenteric defect.

Contributors All the authors conducted the analysis of the described case; RES drafted the manuscript; RAM, SV and JS critically reviewed the manuscript. All authors read and approved the final version.

Competing interests None declared.
Patient consent Consent obtained from guardian.

Provenance and peer review Not commissioned; externally peer reviewed.

(C) BMJ Publishing Group Ltd (unless otherwise stated in the text of the article) 2017. All rights reserved. No commercial use is permitted unless otherwise expressly granted.

\section{REFERENCES}

1 Zelop C, Benacerraf BR. The causes and natural history of fetal ascites. Prenat Diagn 1994; 14:941-6.

2 Abdellatif M, Alsinani S, Al-Balushi Z, et al. Spontaneous resolution of fetal and neonatal ascites after birth. Sultan Qaboos Univ Med J 2013:13:175-8.

3 Nigam A, Kumar M, Gulati S. Fetal ascites and hydrometrocolpos due to persistent urogenital sinus and cloaca: a rare congenital anomaly and review of literature. BMJ Case Rep 2014;2014:bcr2013202231.

Copyright 2017 BMJ Publishing Group. All rights reserved. For permission to reuse any of this content visit

http://group.bmj.com/group/rights-licensing/permissions.

BMJ Case Report Fellows may re-use this article for personal use and teaching without any further permission.

Become a Fellow of BMJ Case Reports today and you can:

- Submit as many cases as you like

- Enjoy fast sympathetic peer review and rapid publication of accepted articles

Access all the published articles

Re-use any of the published material for personal use and teaching without further permission

For information on Institutional Fellowships contact consortiasales@bmjgroup.com

Visit casereports.bmj.com for more articles like this and to become a Fellow 